\title{
The Contributions of Teachers: Nursery the value of Love in the Early Prevention of Radicalism At Middle School Students
}

\author{
Andar Gunawan Pasaribu \\ Institut Agama Kristen Negeri Tarutung \\ pdt.andargunawanpasaribu@yahoo.co.id
}

\begin{abstract}
This writing aims to find the extent of the contribution of Christian Religious Education teachers: raising the value of Love in the early prevention of Radicalism for Junior High School Students. The method used in the writing of this scientific paper is a qualitative method and data collection techniques used by conducting library research by collecting data through books and the internet, conducting direct observations in the field and interviewing the object of study, The conclusion of this scientific work is the contribution of teachers PAK nursery the value of love in preventing radicalism among high school students includes teaching, giving interpreting the values of love, herding students living in values of love, providing guidelines for loving values, being an example in loving values, forming patriot-spirited students in loving values, preparing students to be citizens who live in loving, and spirited values. Nursery the values of love, preventing radicalism. From the research results of the Contribution Teachers: seeding the value of Love in the Prevention of Radicalism among Middle School Students in the District of Tarutung, North Tapanuli Regency $85 \%$ of PAK teachers stated the importance of the program of seeding the value of love in preventing Radicalism among junior high school students
\end{abstract}

Keywords: Contribution of Teachers Christian Religious Education , nursery value love, radicalism

\section{Introduction}

Schools have a role in developing students in three domains: cognitive, affective and psychomotor. In addition, school plays an important role in the nursery of students in facing radicalism. have a contribution in the nursery for students to ward off radicalism through the nursery of mutual love. The nursery for the values of love among junior high school students is an early prevention against radicalism

The value of love is very important to teach and instill from an early age to college. Sowing the values of love is one of the ways to counteract radicalism today. The value of love will deny radicalism.

Because understanding of radicalism can grow from elementary schools, high schools to universities.The series of radicalism takes place in a place of successive learning both in universities. This is evident from the issue of radicalism that lurks on favorite campuses in Indonesia, according to Ansyaad, it is also not only suspected to occur in religious faculties or spiritual activities. Sandrakhsay: "Radicalism is apparently more prevalent in the general education environment [1].

Frans sayThe contribution of education is important in tackling the effects of religious extremism [2]. Especially, Hullsay religious education will provide input on their personal 
development and maturity as religious defenders who are ready to take part in being mature and intelligent in a fully developed society [3].

From the background of the above problems, it is very important that the contribution of Teachers PAK: nursery the value of love in preventing radicalism among junior high school students.. The purpose of this study was to find out how big the contribution of the teacher in sowing the value of love for the prevention of radicalism among junior high school students.

\section{Research Methods}

In this writing the authors use the interview method with data collection techniques relating to the subject that the authors discuss, namely literature, surveys and interviews. Natzir says Interviews, namely data retrieval using questions and answers [4]. Next Sugiyanosays In-depth interviews were conducted to explore the contributions of Teacher's PAK in seeding the value of love in preventing radicalism among middle school students [5].The subjects of the study were the Teacher's PAK se District of Tarutung, North Tapanuli Regency to 5 junior high schools consisting of 12 teachers (SMP Neg.1,2,3,4 and 6), conducted in November 2019. The tool used is a closed question, where the researcher writes the questions that will be asked by the respondent. Respondents will answer: Agree or Disagree.

$$
\text { Percentage }=\mathrm{nR} / \sum \mathrm{R} \times 100 \%
$$

\section{Results and Discussion}

\subsection{Data Analysis and Research Results}

\subsubsection{Contributions of Teachers of PAK : Nursery the value of Loving in Prevention of Radicalism}

\section{a) Giving Teaching and Understanding}

From the interview R1 says "That the emergence of radicalism was caused by the religious shallowness. Furthermore R2 says that "Radicalism arises because in knowing religion is not in accordance with the teachings of Jesus Christ who lives in Love for all people.Next R3says The teaching of Radicalism has a characteristic if you want to not be the same as me, then you are my enemy, you must kill, destroy and destroy.Then R4 says Knowledge that is still lacking on the teachings of Christ then acts of radicalism as an act of radicalism out of love while the teachings of Christ in Love.R5says there for in the teachings of Christ not teach violence, but love.

\section{b) Provide Interpretation of the value of love}

R6 says Teachers'PAK must be able to interpret the scriptures related to the values of love properly. R6 says Teacher's PAK may not interpret Bible texts in a literal way.R7 says Bible interpretation must convey God's truth and the value of love.R8 says Because the conclusion of the law is to love God and love others. 


\section{c) Pastoring students with the value of Love}

Pasaribu says Pastoral care means herding, caring, and attention.R9 says It is the teacher's PAK responsibility to care for and safeguard students' lives in the values of love.R10 says Teachers'PAK are required to advance students' lives well [6]. From the interview R11 said never let students live freely during learning hours, but take care of and care for students by monitoring attention both in the classroom and outside the classroom.student will not be radicalism.

\section{d) Provide guidelines for the value of love}

R12 says Teachers' PAK provide guidelines for loving values for students.R1 says The guidebook for the value of love is very important so that there are those who are guided by middle school students, so students can guide the values of love in their lives, With teachers PAK providing guidelines for the value of love, students do not become misguided.

\section{e) Evangelize students to become believers in Jesus}

R2 says Teacher's PAK Evangelism to students builds the trust and faith of middle school students. R3 says:with students having faith and trust in Jesus, students have the power of God to deny and fight the seduction of radicalism. R4 says Evangelism makes high school students do the value of love.

\section{f) Form patriot-minded students (heroes) values of love}

R5 says teacher's PAK form heroic-loving students today. R6 says Student become warriors who spread patience, generosity, arrogance, politeness, forgiveness, hope and insurers of all things. R7 says with a patriot spirit, students dare to show the value of love in their relationships and friendships, and dare radicalism.

\section{g) Become a facilitator}

R8 says teacher PAK being a facilitator means providing material about loving values.R9 says teacher's PAK facilitate the atmosphere, conditions and environment that can live in loving values.

\section{h) Giving motivation}

R10 says motivation to stimulate students can influence a behavior. R11 says Providing motivation for Teachers' PAK by giving praise, gifts, rewards so that students appreciate, understand and do the values of love. R12 says Motivation provided by teachers PAK is an incentive to grow in the value of love.R1 saysteachers PAK provide motivation is an act of fertilizing the values of love to grow in students.

\section{i) Provide Counseling}

R1says Students are very difficult to do the value of love if he has problems of life problems.R2 saysThe teacher PAK is responsible for helping students solve their problems. R3saysBecause the purpose of Christian Counseling is to investigate students' problems, help 
the counselee get an explanation of the problem, help the counselee make plans to deal with or solve problems and make Christians grow in their faith.

\section{j) Provide Guidance}

Pasaribu says Guidance is a guidance that can help and direct someone.teachers PAK in mentoring help and direct students to be able to act in the values of love [7]. R4 says teacher guidance about values love.

\subsubsection{The Problem of Christian Religious Education Teachers: Nursery the values of love in the Prevention of Radicalism.}

From the interviews conducted with respondents, there were problems in sowing the value of love for preventing radicalism.

\section{a) Problems Personality of Students}

R5 says Teachers PAK expressed difficulties in developing the values of love because students have problems in the family and the transition period (transition) from childhood to youth.Associated with it, R6 says student SMP struggle with identity, personality and friendship. The nature of Shiva is still unstable and easily influenced.

\section{b) Environment}

R7 says The second problematic of teachers PAK in contributing is environmental factors. Next R8 The family environment lacks direction and understanding in preventing radicalism. Associated with it R 9 says Parents pay less attention to what students are doing because of lack of control.

\section{c) Curriculum PAK}

R10 says In the curriculum there is less emphasis on raising the value of love in preventing radicalism.Cultivation and teaching about the value of love were interrupted until grade 8.Associated with it R11 says curriculum PAK needed to development.

\section{d) Extracurricular activities}

R1 says in extracurricular activities carried out by students less involving in coaching about the values of love. Next R2 says Extracurricular do not include training and creative activities to raise the value of love in preventing radicalism. Then R3 says extracurricular activities are only activities in mathematics, language and arts.

\section{e) School Student Organizations (OSIS)}

R4 says the student council can be used as a means of raising the value of love. Next R5 says but in reality the student council is less effective in raising the value of love. Then R6 says the means of student council are not utilized in habituating the values of love. 


\section{f) Morning Service Activities}

R7 says Worship are indeed useful in seeding the values of love. R8 says But all this time the theme of the sermon in the morning service was still free. Associated with it, R 9 says Workship are conducted in the mental development of children.

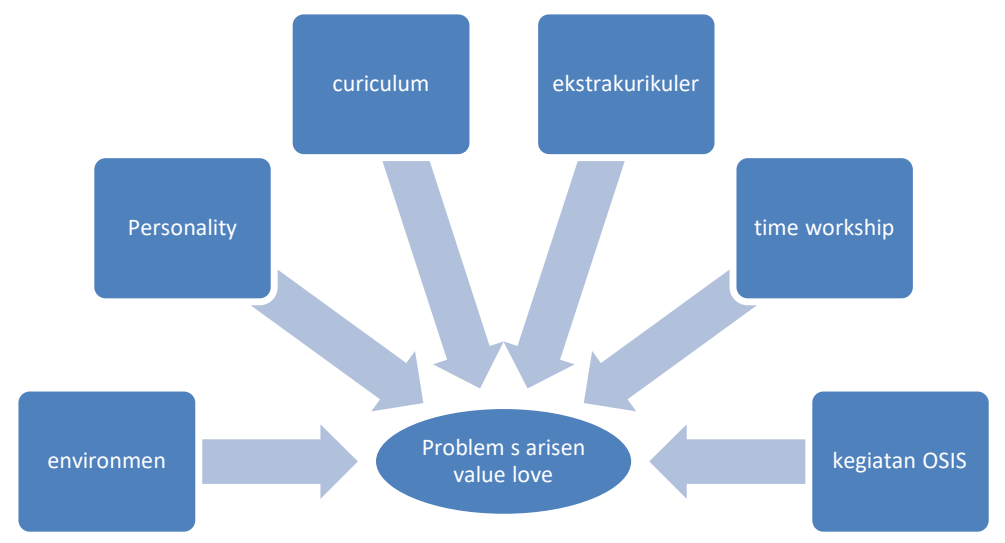

Fig.1. The illustration of the problems above

\subsubsection{Analysis of the Contribution of Christian Religious Education Teachers}

The analysis obtained from the interview results :

\section{a) Teaching and Understanding Program}

From the results of interviews with teachers PAK, $80 \%$ of teachers PAK in Tarutung Subdistrict SMP stated that it is necessary to improve the curriculum PAK in starting grades $7-9$, to add material on the values of love and radicalism.

\section{b) Assistance Program}

From the interview results $80 \%$ stated the need for a mentoring program about the values of love and radicalism. This assistance program is given by teachers PAK to accompany and direct what should be done and what should be left behind.

\section{c) Counseling Program}

From the interview results $85 \%$ stated that they had already conducted a counseling program, but needed to involve teachers PAK in seeding the value of love in the early prevention of Radicalism. The Counseling Program is conducted by teachers PAK to students in order to help students overcome their problems, so that students get out of problems and enter the seeding of love in preventing radicalism. 


\section{d) Pastoralism Program}

From the results of the interview $85 \%$ of teachers PAK do grazing. Pastoral care programs where teachers PAK pay attention to, serve,workship, maintain and foster the value of love in students' lives.

\section{e) Motivation Program}

From the results of the interview $85 \%$ of teachers PAK still provide motivating programs for children with high grades, but students who do love values will be considered later. The motivating program can be done by giving memorized yells that are memorized every day, and giving rewards to students who do love values.

\section{f) Evangelism Programs}

From the interviews, only $90 \%$ of teacher's PAK stated that they had not yet conducted an evangelistic program. But evangelism programs are very important in making students believe in Jesus Christ. Through faith and trust in Jesus, students have the power to fight the enticements of radicalism.

\section{g) Innovation Program}

From the results of interviews 80 of the teacher's PAK stated that extracurricular activities can be used as an innovation program for junior high school students. The Innovation Program aims to develop a critical, creative attitude and develop abilities and solve the problem of radicalism.

\section{h) Program Formation Soul Patriot' Pancasila}

From the interviews, $90 \%$ of the actual Patriot Pancasila soul formation programs can be carried out through student council activities. Program Formation Pancasila Soul for SMP becomehero and fighters of the values of love in maintaining Pancasila.

\section{i) Facilitator Program}

From the interviews, $85 \%$ of teachers PAKstated that the facilitator program was very important, facilitating students to be able to do the values of love.R8 says The facilitator program is that PAK teachers facilitate students to be able to do and do the values of love.

\section{answer's responden}

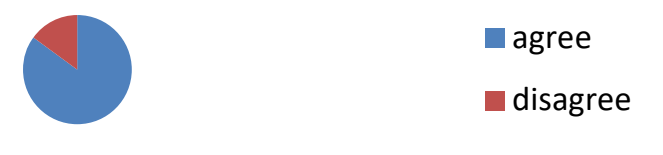

Fig.2. Describtion From the results of the agreed and disagree answers 


\subsection{Discussion}

\subsubsection{Radicalism}

Cormack say The word Radicalism comes from the Latin radix which means root [8]. In the Cambridge [9], KBBI refer: :Radical is a belief or expression of trust in which there are extreme social or political actions for major changes.Radicalism is a school of thought that requires drastic change [10].Next Bittner say The psychology of radicalism holds that radicals have" personality traits of dependence, rigidity, [and] sadomasochism, "which ignites negative thing [11].

Corenosay Radicalism lately, the concept of radicalism which is familiar with violence, is exclusive, tends to be embedded in certain religious movements, whose teachings are based on the understanding of scripturalism, fundamentalism and Puritanism [12]. Net Frans say: Religious radicalism is a religious behavior that requires a drastic change by taking a hard character that aims to realize certain targets [13].Qodirsay This extreme attitude breeds in the middle of the stage which shows poverty, social inequality, or injustice [14].Then Browne say These forms of violence can be theological, psychological, physical, social and political in nature, even violence within the framework of discourse [15].

\subsubsection{Nursery values of Love}

Development values of love with nursery. John say The word nursery comes from the verb semai.Nursery means to sow, to plant, to nurture, to cultivate, and to maintain [16].Paul say Nursery functions to make students grow and have quality [17]. Nursery is an action taken in the context of sowing, planting, nurturing, fertilizing and maintaining a seed or value.

Whereas Paul say the value of love is found in 1 Corinthians 13: 4-8, which is patience, generous, not jealous, not boastful and not arrogant, not doing anything rude, not looking for one's own benefit, not angry, not distorted,other people's faults, not rejoicing because of injustice, covering up everything, believing in everything, hoping for everything, enduring all things, and bringing blessings [18]. Next Pfitzer say the values of love relate to fellow human beings, a characteristic that love always believes in and does the best for others. Then Brill (tt, 269) say Love does not force your own will, does no harm to others [19].

\subsubsection{Contribution teacher of PAK: Nursery values loves}

KBBI say The word contribution is meaningful participation, involvement, involvement as well as contribution and has a contribution [20]. Next John saysContributions can be given in various fields, namely thought, leadership, professionalism, finance, and others [21].

According HariantoContributions of teachers' PAK nursery the value of love is to be a shepherd for his students, to be an example and a leader, to be an evangelist who is responsible for the surrender of each of his students to Jesus Christ, to be a facilitator, to be a guide and to be a motivator [22]. Groom $(2011,56)$ says The task of the teacher 's PAK to emulate the agape-loving life of God by loving our neighbor [23].PLPGrefer the teacher's PAK job is to educate, teach and train students, transform intelligence and experience of faith in students, instill Christian values, social fellowship values, educate the community in schools and their homes to be role models, shape students to be patriot and spirit of Pancasila, preparing students to be good citizens and citizens of God's work [24]. 


\section{Conclusion}

From the results of research conducted through qualitative methods using interviews, the contribution of Teachers PAK is obtained: seeding the value of love in preventing radicalism among junior high school students, namely teaching, providing grazing, providing counseling, providing assistance and coaching, providing evangelism, providing examples, giving a role model motivation, shape the soul of a student's partriot, provide innovation, provide a facilitator, and make students a good citizen.

The tools used in contributing: raising the values of love in preventing radicalism are learning curricula, student organizations, extracurricular activities, motivational programs, innovation programs, evangelistic programs, evangelistic activities once a week and Christian activities.

From the research results of the Contribution of PAK Teachers: seeding the value of Love in the Prevention of Radicalism among Middle School Students in the District of Tarutung, North Tapanuli Regency $85 \%$ of PAK teachers stated the importance of the program of seeding the value of love in preventing Radicalism among junior high school students.

\section{References}

[1] https://www.voaindonesia.com/a/bnpt-radikalisme-marak-di-perguruan-tinggi133451968/100501.html di download pada hari 10 Nopember 2019.

[2] Frans Emanuel da Santo, https://komkat-kwi.org/2019/07/24/profil-dan-peran-katekis-dalammenghadapi-radikalisme-berbasis-agama/

[3] Hull, J.M., 1993: The Nature of Religious Education. Distinctive Aspects of Baha'i Education: Proceedings of the Third Symposiumon Baha'i Education, The Baha'i Publishing Trust

[4] Herman,Thelma McCormack, 1947, "The Motivation of Radicals," in Ralph Turner and Lewis Killian (eds.), Collective Behavior Englewood Cliffs, NJ: Prentice, 433-443

[5] Cambridge University, 2008,Cambridge Advanced Leraners Dictionary, (Singapore: Cambridge University Press, , hlm. 1170.

[6] Departemen Pendidikan dan Kebudayaan. 1995. Kamus Besar Bahasa Indonesia, (Edisi Kedua), Jakarta: Balai pustaka

[7] Bittner, Egon , 1963: ,"Radicalism and the Organization of Radical Movements," American Sociological Review 28, 928-940.

[8] Coreno. Thaddeus 2002 "Fundamentalism as a Class Culture", Sociology of Religion,Vol. 63, No. 3, 335-6.

[9] Frans Emanuel da Santo, https://komkat-kwi.org/2019/07/24/profil-dan-peran-katekis-dalammenghadapi-radikalisme-berbasis-agama/

[10] Qodir, Zuly Radikalisme Agama di Indonesia, 2014,Yogyakarta: Pustaka Pelajar, hlm. 117.

[11] Browne Kevin O.. 2001. Lanskap Hasrat dan Kekerasan, terj. Apri Danantor, et.al.,Yogyakarta:Jendela bekerjasama dengan Yayasan Adikarya IKAPI dan The Ford, 18

[12] Echols ,John M., 1975, Kamus Ingris- Indonesia, Jakarta: Gramedia, ,398

[13] Ellingworth dan Howard Harton, 2013. Pedoman Penafsiran Alkitab Surat Pertama kepada Jemaat di Korintus, Jakarta:LAI dan Yayasan Kurnia Budaya Indonesia,347

[14] Barclay, William, 2009, Pemahaman Surat 1 dan 2 Korintus, Jakarta: BPK Gunung Mulia, 221.

[15] Pfitzer, V.C, 2010, Ulasan 1 Korintus, Kesatuan dalam kepelbagaian, Jakarta : BPKGunung Mulia, 254. Brill , J. Wesley, Tafsiran Surat Korintus Pertama, Bandung: Yayasan Kalam Hidup, tt, 269

[16] Pusat BahasaKamus Besar Bahasa Indonesia (Jakarta: Gramedia Pustaka Utama, 2008 ), Ed. 3, 1024 
[17] End, Th.van den, 1995, Tafsiran Alkitab, Surat Roma, Jakarta: BPK Gunung Mulia, 615

[18] P., Harianto G, 2012, Pendidikan Agama Kristen dalam Alkitab \& Dunia Pendidikan Masa Kini, Yogyakarta: Andi, , 158-159.

[19] Groom, Thomas H., 2011, Chritian Religious Education (Pendidikan Agama Kristen), Jakarta: BPK Gunung Mulia, 56

[20] PLPG PAK, 2008, Pedoman Teknis Pendidikan dan Latihan Profesi Guru (PLPG ) Pendidikan Agama Kristen (PAK), LPTK Induk, STT Jakarta, , 38

[21] Moh. Natsir, 1988,Metode Penelitian Jakarta: Ghalia Indonesia, 211

[22] Sugiyono, , 2010 Metode Penelitian Pendidikan; Pendekatan Kuantitatif, Kualitatifdan R\&D (Bandung: ALFABETA, 310-330

[23] Pasaribu Andar Gunawan , 2012, Pelayanan Pastoral Konseling Yang Dinamis Di Gereja dan Sekolaj, Medan:Mitra, 4.

[24] Pasaribu Andar Gunawan, Konseling Kristen di Sekolah, Medan : Penerbit Mitra Group, $2019,9$. 